\title{
Are the Pyrenees a barrier for the transport of birch (Betula) pollen from Central Europe to the Iberian Peninsula?
}

\author{
Rebeca Izquierdo ${ }^{\mathrm{a}}$, Marta Alarcón ${ }^{\mathrm{a}, *}$, Jordi Mazón ${ }^{\mathrm{a}}$, David Pino ${ }^{\mathrm{a}, \mathrm{e}}$, Concepción De Linares ${ }^{\mathrm{b}, \mathrm{c}}$, \\ Xabier Aguinagalde ${ }^{\mathrm{d}}$, Jordina Belmonte ${ }^{\mathrm{b}, \mathrm{c}}$ \\ ${ }^{a}$ Departament de Física, Universitat Politècnica de Catalunya (UPC),Avda. Eduard Maristany 10-14. 08019 Barcelona, Spain \\ ${ }^{\mathrm{b}}$ Departament de Biologia Animal, Biologia Vegetal i Ecologia, Universitat Autònoma de Barcelona (UAB), Edifici C, 08193 Bellaterra, Spain \\ ${ }^{\mathrm{c}}$ Institut de Ciencia i Tecnologia Ambientals (ICTA), Universitat Autònoma de Barcelona (UAB), Edifici Z, 08193 Bellaterra, Spain \\ d Laboratorio de Salud Pública. Dirección de Salud Pública y Adicciones. Departamento de Salud del Gobierno Vasco, c/Santiago 11, 01008 Vitoria-Gasteiz, Spain \\ ' Institut d'Estudis Espacials de Catalunya (IEEC-UPC), Gran Capità 2-4, 08034 Barcelona, Spain
}

\section{A R T I C L E I N F O}

Article history:

Received 4 May 2016

Received in revised form 21 September 2016

Accepted 23 September 2016

Available online xxx

Keywords:

Aerobiology

Pollen long-range transport

Source-receptor model

Birch pollen in Spain

\section{A B S T R A C T}

This work provides a first assessment of the possible barrier effect of the Pyrenees on the atmospheric transport of airborne pollen from Europe to the North of the Iberian Peninsula. Aerobiological data recorded in three Spanish stations located at the eastern, central and western base of the Pyrenees in the period 2004-2014 have been used to identify the possible long range transport episodes of Betula pollen. The atmospheric transport routes and the origin regions have been established by means of trajectory analysis and a source receptor model. Betula pollen outbreaks were associated with the meteorological scenario characterized by the presence of a high-pressure system over Southern British Islands reinforced by a low-pressure system over Morocco and Southern Iberian Peninsula. France and Central Europe have been identified as the probable source areas of Betula pollen that arrives to Northern Spain. However, the specific source areas are mainly determined by the particular prevailing atmospheric circulation of each location. Finally, the Weather Research and Forecasting model highlighted the effect of the orography on the atmospheric transport patterns, showing paths through the western and easternmost lowlands for Vitoria-Gasteiz and Bellaterra respectively, and the direct impact of air flows over Vielha through the Garona valley.

C) 2016 Published by Elsevier Ltd.

\section{Introduction}

Pollination is a biologically-relevant process that affects the structure of ecosystems, since pollen is responsible for gene flow (Ellstrand, 1992; Ennos, 1994; Burczyk et al., 2004; Belmonte et al., 2008), and it contributes to determine the spatial distribution of plant species (Ellstrand, 1992; Smouse et al., 2001; Sharma and Khanduri, 2007; Schmidt-Lebuhn et al., 2007; Belmonte et al., 2008). On the other hand, airborne pollen released into the atmosphere by anemophilous plants can induce allergic symptoms in the atopic population, and also increase the sensitization of the overall population (D'Amato et al., 2007). Currently, it is widely accepted that pollen released to the atmosphere can be transported large distances under favourable meteorological conditions (Sofiev et al., 2012). Therefore, airborne pollen transport is becoming increasingly important due to its implications in terms of biogeography and public health.

It is well known that the orography of the European mountain systems has been a strong influence on the biogeography and evolution of mountain and high latitude species (Schmitt, 2009; Karrer et al., 2015). The Pyrenean chain is a major mountain range in SW Europe. Due to its elevation (up to $3400 \mathrm{~m}$ ) and its spatial extent (>400 km) this chain is an altitudinal obstacle between the Iberian Peninsula and

* Corresponding author.

Email address: marta.alarcon@upc.edu (M. Alarcón) the rest of Europe that has strongly affected the distribution and genetic structures of native species (Haran et al., 2015). However, are the Pyrenees a real barrier for the atmospheric transport of pollen between Europe and Iberian Peninsula?

In this context, birch (Betula sp. hereafter Betula) pollen has been selected to study the long range transport of pollen across the Pyrenees. On the one hand, Betula trees produce large amounts of highly allergenic pollen, particularly it has been estimated that on average each inflorescence produces 10,044,000 pollen grains (Piotrowska, 2008), ranging from 1000 to 10,000 pollen grains $/ \mathrm{m}^{3}$ the daily average of airborne Betula pollen concentrations observed during the peak birch pollen season in Northern Europe (Ranta et al., 2008). Betula pollen is distributed by wind and impacts human health by causing seasonal hay fever, pollen-related asthma, and other allergic diseases (Müller-Germann et al., 2015), being one of the most important causes of respiratory allergy in Northern and Central Europe (Emberlin et al., 1993, 1997; Spieksma et al., 1995; Heinzerling et al., 2009). On the other hand, Betula trees are abundant in Central, Northern and Eastern Europe, but are scarce in the Mediterranean territories, especially in Spain, of which northern regions constitutes a southern border of the distribution area (De Bolòs et al., 1990). Betula pubescens has a more northerly and easterly distribution, whereas Betula pendula can reach southern regions such as Iberian Peninsula, South Italy and Greece (Beck et al., 2016; Fig. 1). Airborne Betula pollen is present in Spain from March to the end of 


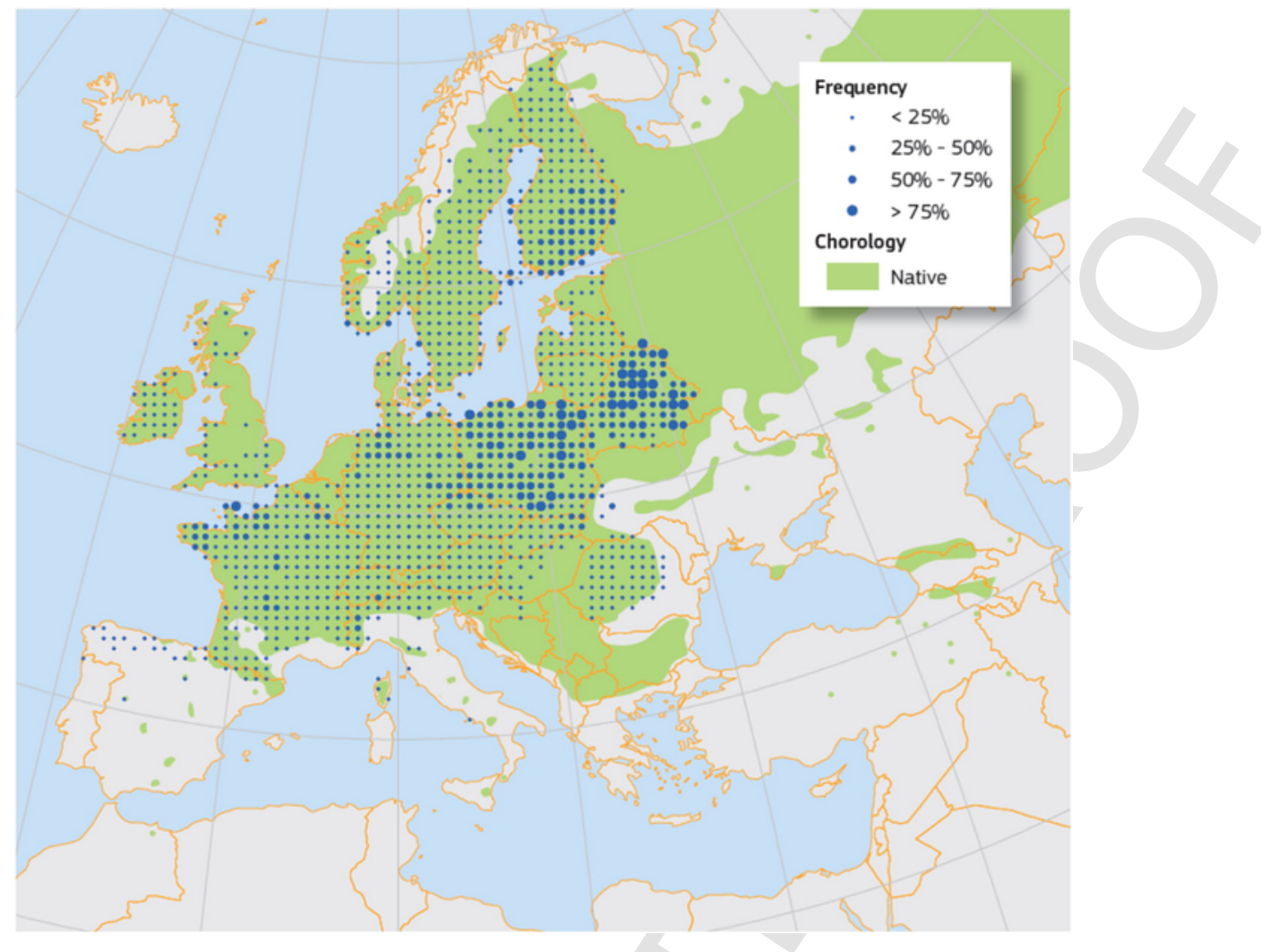

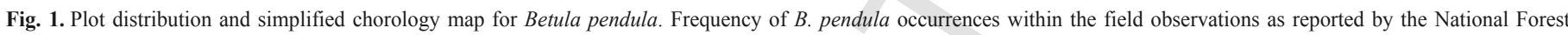
Inventories (Beck et al., 2016).

May, and it only reaches high concentration in the $\mathrm{N}$, being the highest concentrations recorded in the NW corner of the Iberian Peninsula (Jato et al., 1999). Nevertheless, punctual peaks are observed in other N Iberian Peninsula zones due to the long-range transport (LRT thereafter) under particular meteorological circumstances (Sofiev et al., 2015). This is especially important in Catalonia (NE Spain), where allergy to Betula pollen is not very frequent (Pereira et al., 2006), but it occurs and the intensity of derived health problems can be increased by LRT pollen episodes. These potential allergenic diseases outbreaks have been previously registered for other allergenic pollen types in Catalonia, such as Ambrosia (Belmonte et al., 2000; Fernández-Llamazares et al., 2014) and Fagus (Belmonte et al., 2008). Conversely, Betula pollen is a common cause of pollinosis in localities in NW Spain, where birch trees are more abundant, and between $13 \%$ and $60 \%$ of individuals who are immunosensitive to pollen grains respond positively to its allergens (Aira et al., 2001; Dopazo, 2001). As a result, models for short-time forecast of airborne birch pollen concentrations were developed in NW Spain and good forecasting results were obtained (Cotos-Yáñez et al., 2004), despite LRT was not included.

In Europe, back-trajectory modelling has been used to identify the arrival of Betula pollen from remote sources in Denmark (Mahura et al., 2007; Skjøth et al., 2007), Lithuania (Veriankaite et al., 2010), and United Kingdom (Skjøth et al., 2009, 2015). Additionally, System for Integrated modeLling of Atmospheric coMposition (SILAM) simulations have been applied to trace the origin of LRT of airborne Betula pollen in Finland (Sofiev et al., 2006; Siljamo et al., 2008), Russia (Siljamo et al., 2008) and Lithuania (Veriankaite et al., 2010). Recently, the Monitoring of Atmospheric Composition and Climate (MACC, http://www.gmes-atmosphere.eu) regional multi-model sim- ulations of Betula pollen dispersion in Europe (Sofiev et al., 2015) also showed that the models successfully reproduced the timing of the pollen season. However, absolute pollen concentrations during the season were underestimated in the southern part of the birch habitat (Sofiev et al., 2015).

Atmospheric back-trajectories and transport models have been profusely used to infer potential sources at receptor locations and identifying the physical location of their origin (Stohl, 1996; Begum et al., 2005; Fleming et al., 2012). Several statistical trajectory based approaches are used in source-receptor studies to identify probable emission sources by combining the trajectories with measured concentrations. For the interpretation of source areas of pollutants, the potential source contribution function (PSCF) (Ashbaugh, 1983), Seibert's concentration field methodology (Seibert et al., 1994) and Stohl's redistributed model (Stohl, 1996) have been extensively used (Charron et al., 2000; Polissar et al., 2001; Hoh and Hites, 2004; Salvador et al., 2004). Recently, the source-receptor methodologies have also been applied to identifying probable source regions of pollen (Belmonte et al., 2008; Izquierdo et al., 2011; Fernández-Llamazares et al., 2014).

In this study, we explore the possible barrier effect of the Pyrenees on the atmospheric transport of airborne pollen from Europe to N Iberian Peninsula. Aerobiological data recorded in three Spanish stations located in the eastern, central and western areas downwind the Pyrenees in the period 2004-2014 have been used to identify the possible LRT episodes of Betula pollen. The region where the pollen was originated has been established by means of trajectory statistical analysis using Hybrid Single-Particle Lagrangian Integrated Trajectory (HYSPLIT) model. The spatial resolution of the atmospheric transport models has a direct effect on the quality of the simulations, 
and in the case of the pollen, this has special relevance in areas with complex orography in which the pollen transport is widely governed by complex flows (Skjøth et al., 2002). The nested mesoscale Weather Research and Forecasting (WRF) model was used for simulating specific episodes at higher resolution. In addition, a source receptor model was applied to the Betula pollen records to determine the source regions. The meteorological scenarios that favour this transport were also characterized in order to better understand the influence of LRT in the pollen records downwind from the Pyrenees area.

\section{Material and methods}

\subsection{Pollen record}

Daily Betula pollen concentrations recorded during the birch flowering season (from 1st March to 31st May) at three pollen-monitoring sites located in N Spain for the period from 2004 to 2014 are featured in this study (Fig. 2): Bellaterra $\left(41^{\circ} 30^{\prime} \mathrm{N} 2^{\circ} 06^{\prime} \mathrm{E}, 245 \mathrm{~m}\right.$ above sea level (m a.s.1.), Vielha $\left(42^{\circ} 42^{\prime} \mathrm{N} 0^{\circ} 47^{\prime} \mathrm{E}, 980 \mathrm{~m}\right.$ a.s.l.) and Vitoria-Gasteiz $\left(42^{\circ} 21^{\prime} \mathrm{N} 2^{\circ} 06^{\prime} \mathrm{W}, 520 \mathrm{~m}\right.$ a.s.1.). Samples were obtained using volumetric suction pollen-spore trap based on the impact principle (Hirst, 1952), the standardized method in European aerobiological networks. Daily average pollen concentrations were calculated following the standardized Spanish method (Galán Soldevilla et al., 2007), consisting in analysing four continuous longitudinal sweeps along the 24 h daily slides. Pollen concentrations were expressed as the number of pollen grains per cubic meter of air $\left(\operatorname{pollen} / \mathrm{m}^{3}\right)$. The Annual Pollen Index (API) is defined as the sum of the mean daily pollen concentrations over the year.

Bellaterra has been chosen as control-station in order to isolate LRT of Betula pollen that arrives to the Iberian Peninsula coming from Europe, since the other two stations are influenced by local/regional pollen sources. Two threshold values were used to select Betula pollen outbreaks that reached Bellaterra: (1) daily peak pollen concentrations $>10$ pollen $/ \mathrm{m}^{3}$, and (2) pollen sum in the episode $>20 \mathrm{p}$. The hypothesis of this study is that differences between pollen dynamics in the control-station Bellaterra and the rest of stations could be related to different atmospheric transport patterns. Therefore, $B e-$ tula pollen peak episodes detected at control-station Bellaterra were sorted into two groups in order to identify the different atmospheric transport patterns: (1) simultaneous pollen peaks at the three sampling stations and (2) non-simultaneous peaks, which corresponded to pollen peaks observed exclusively at the control-station.

\subsection{Meteorological modelling}

\subsubsection{HYSPLIT back-trajectories}

A daily analysis was undertaken based on 96-h isentropic back-trajectories with segment end points of 60-min at 00:00 $\mathrm{h}$ and 12:00 h UTC and $1500 \mathrm{~m}$ a.s.l. at each sampling station from March to May for the 2004-2014 period by using the HYSPLIT 4.0 dispersion model from the Air Resources Laboratory (ARL, available at http://www.arl. noaa.gov/ready/hysplit4.html, Draxler and Rolph, 2003). This height (1500 $\mathrm{m}$ a.s.1.), corresponding to $850 \mathrm{hPa}$ standard pressure level, can be taken as representative of the mean atmospheric transport at a synoptic scale within the upper boundary layer (Izquierdo et al., 2014). This layer is typically sensitive to cyclonic wave features, and is the approximate boundary between the surface wind regime and the free troposphere (Artz et al., 1985). Moreover, a relationship between the $850 \mathrm{hPa}$ wind direction and the prevailing weather patterns associated with the passage of cyclonic waves is well established (Dayan and Lamb, 2003). The meteorological input was obtained from the NCEP (National Center for Environmental Prediction) using the NCEP/NCAR reanalysis database.

The flow direction for the date of the concentration peaks in the Betula pollen time series of Bellaterra was analysed with HYSPLIT back-trajectories in the three sampling stations in order to estimate potential source regions and classify the LRT episodes in simultaneous and non-simultaneous pollen peaks.

\subsubsection{Meteorological scenarios characterization}

In addition to the above procedure, a determination of the meteorological scenarios causing the simultaneous Betula pollen outbreaks over the three sampling stations was carried out by means of the analysis of: (1) mean sea level pressure, (2) geopotential height at $850 \mathrm{hPa}$, and (3) geopotential height at $700 \mathrm{hPa}$. These are the standard vertical levels commonly used in synoptic scale analysis: $850 \mathrm{hPa}$ corresponding to the $1500 \mathrm{~m}$ height of the computed back-trajectories and $700 \mathrm{hPa}$ corresponding to $3000 \mathrm{~m}$. The daily data

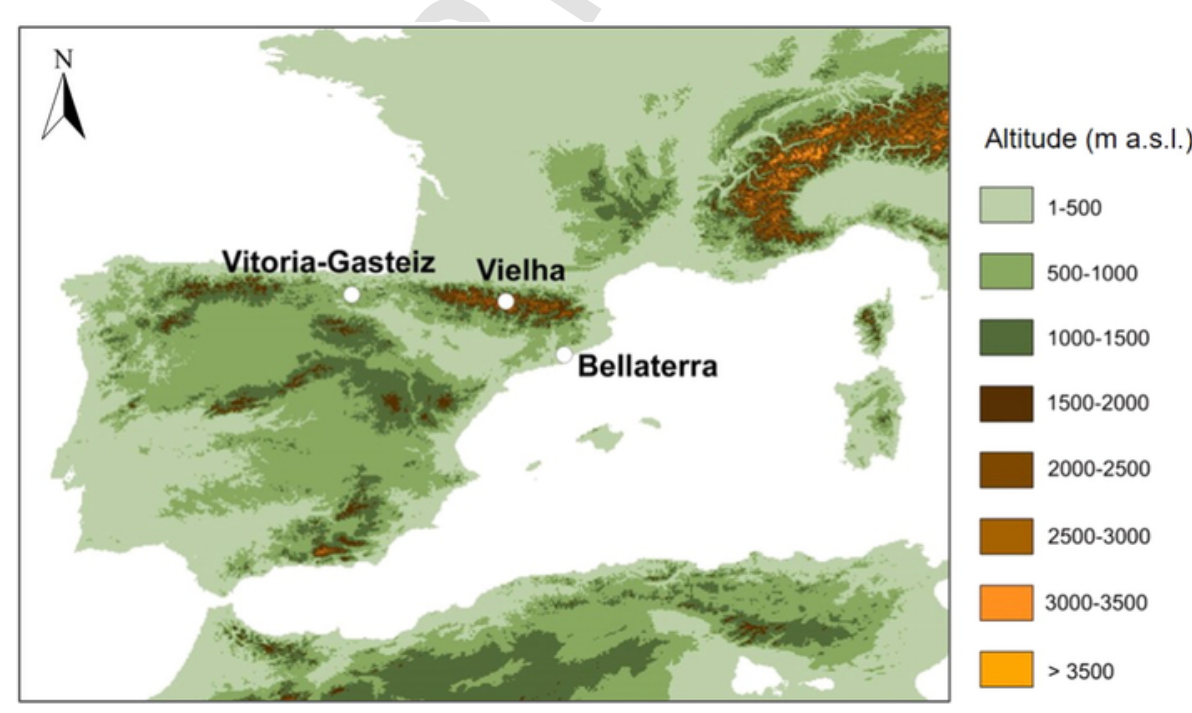

Fig. 2. Geographical location of the study area and the aerobiological sampling stations. 
files were obtained from the European Centre for Medium-Range Weather Forecasts (ECMWF; [accessed September 8, 2015], http:// apps.ecmwf.int/datasets/) using the ERA-Interim reanalysis datasets. The synoptic scenarios were obtained from the averaged data of mean sea level pressure and geopotential height of the simultaneous peak days.

\subsubsection{Mesoscale modelling}

To better understand the atmospheric transport of Betula pollen in a region with complex orography such are the Pyrenees, the effects of mesoscale circulation (4-400 km) were incorporated. To this end, version 3.3 of the nested Weather Research and Forecasting (WRF) mesoscale model (Skamarock et al., 2008) was used to simulate, at high resolution, the specific meteorological situations corresponding to two study cases of LRT representative of simultaneous and non-simultaneous pollen episodes: (1) the simultaneous Betula pollen peak episode recorded on the 26th of April 2004, and (2) the non-simultaneous peak episode detected on the 27th of April 2006. For these specific situations, back-trajectories were computed at 100, 700 and $1500 \mathrm{~m}$ a.s.l from the velocity fields obtained from the WRF simulations. Three nested domains were defined with 18 (D1), 9 (D2) and 3 (D3) $\mathrm{km}$ of horizontal grid spacing in both events, having $150 \times 150$, $220 \times 193$ and $148 \times 148$ points, respectively. The simulation in the 2004 case started on the 21th of April 2004 at 00:00 UTC and ran for $162 \mathrm{~h}$; in the case of year 2006 the simulation started on the 22th of April 2006 at 00:00 UTC and lasted for $144 \mathrm{~h}$. In both cases, the boundary conditions were updated every $6 \mathrm{~h}$ by using ECMWF operational model data, which also provided the initial conditions. In both simulations, $44 \eta$-levels were used. For the PBL parameterization, we used the MRF scheme (Hong and Pan, 1996), the RRTM scheme for long wave radiation (Mlawer et al., 1997), the Dudhia (1989) scheme for shortwave radiation, and a 6-class radiation (Hong et al., 2004) for the microphysical parameterization. For the land-surface scheme we used Noah model (Chen and Dudhia, 2001), and for surface layer scheme MYJ model (Janjic, 1996a, 1996b). No cumulus parameterizations were used in the smallest domain.

\subsection{Source-receptor model}

Source-receptor methodologies establish relationships between a receptor point and the probable source areas. To this end, daily HYSPLIT 72-h back-trajectories at 00 and 12 UTM and $1500 \mathrm{~m}$ a.s.l. were used. Each back-trajectory was associated to the corresponding daily pollen abundance. Source-receptor methodologies were applied to: (1) the complete set of daily pollen data from the 1st of March to the 30th of May for the 2004-2014 period at the three sampling stations, and (2) the days with simultaneous Betula pollen peak. A grid, in our case with 2601 cells of $1^{\circ} \times 1^{\circ}$ latitude and longitude, was then superimposed on the integration region of the trajectories in order to map the contributing areas.

A mean pollen concentration is computed for each grid cell based on the residence time of the trajectories in the cells:

$$
C_{i j}=\frac{\sum_{l} n_{i j l} C_{l}}{\sum_{l} n_{i j l}}
$$

where $\mathrm{Cij}$ is the concentration in the cell $(\mathrm{i}, \mathrm{j}), 1$ is the index of the trajectory, $n_{i j l}$ is the number of time steps of the trajectory 1 in the cell $(\mathrm{i}, \mathrm{j})$, and $\mathrm{C}_{1}$ is the pollen concentration measured at the receptor point corresponding to the trajectory 1 . To reduce the cell's local variability (random noise), a smoothing was applied and the value of each cell was replaced by the average between the cell and its eight neighbouring cells. A final filter excluded cells with $<45$ end points, thus producing a more interpretable image. The obtained field map reflects each cell contribution to the pollen concentration at the receptor point.

\section{Results}

\subsection{Birch pollen dynamics in the study area}

Betula APIs recorded in the 10-year study period 2004-2014 ranged between 266 and 1832 pollen grains in Vitoria-Gasteiz, 916-3867 in Vielha and 87-487 in Bellaterra (Table 1). The highest mean API was recorded in Vielha with 2186 pollen grains, followed by Vitoria-Gasteiz with 700, and Bellaterra with 179 (Table 1). Temporal trends of Betula API observed in the three sampling stations during the 2004-2014 period were non-significant $\left(p>0.05 ; \mathrm{R}^{2}<0.3\right)$.

\subsection{LRT outbreaks of birch pollen from 2004 to 2014}

Ten LRT outbreaks of Betula pollen were detected from 2004 to 2014. Six of these ten episodes registered Betula pollen peak values higher than 30 pollen $/ \mathrm{m}^{3}$ at the control-station Bellaterra, and the rest ranged between 10 and 30 pollen $/ \mathrm{m}^{3}$ (Table 2). Pollen concentrations registered during the pollen peak day at the control-station Bellaterra during the Betula pollen outbreaks of pollen detected in the period 2004-2014 ranged between 11 and 146 pollen $/ \mathrm{m}^{3}$ in Bellaterra, $1-135$ pollen $/ \mathrm{m}^{3}$ in Vitoria-Gasteiz and $1-293$ pollen $/ \mathrm{m}^{3}$ in Vielha. The pollen sum recorded during the LRT episodes varied between 21 and 237 pollen grains in Bellaterra, 39-491 Vitoria-Gasteiz and $7-990$ Vielha, which accounted for $18-77 \%$ of the API, $7-72 \%$ and $0-45 \%$ respectively (Table 2 ).

Analysing the time series there were seven LRT episodes during which peak concentrations of Betula pollen were observed simultaneously at the three sampling stations in front of three that exclusively at the control-station Bellaterra (Table 2). Back-trajectories were used to infer the origin of the air masses reaching the stations for these particular days. Fig. 3 shows that back-trajectories of days with simultaneous Betula pollen peaks at the three sampling stations, which came from France and Central Europe. However, back-trajectories that arrived at Vitoria-Gasteiz had a more westerly path forming an Atlantic arc over W France, while back-trajectories arriving to Vielha and Bellaterra crossed over the Mediterranean coast of France.

Table 1

Annual Pollen Index (API) registered for Betula pollen in the three pollen-monitoring sites for the 10-year period 2004-2014 (pollen grains).

\begin{tabular}{llll}
\hline Year & Vitoria-Gasteiz & Vielha & Bellaterra \\
\hline 2004 & 1332 & 2324 & 487 \\
2005 & 480 & 2296 & 87 \\
2006 & 557 & 1295 & 219 \\
2007 & 619 & 957 & 301 \\
2008 & 553 & 2169 & 91 \\
2009 & 331 & 1905 & 177 \\
2010 & 1832 & 3442 & 118 \\
2011 & 843 & 916 & 97 \\
2012 & 462 & 2939 & 90 \\
2013 & 423 & 3867 & 113 \\
2014 & 266 & 1942 & 194 \\
API mean 2004-2014 & 700 & 2186 & 179 \\
\hline
\end{tabular}


Table 2

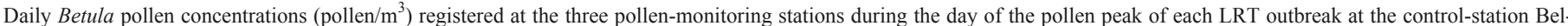

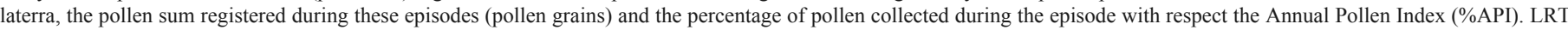
episodes of Betula pollen were sorted into two groups: (1) simultaneous pollen peaks registered at the three stations (S) and non-simultaneous peaks (NS).

\begin{tabular}{|c|c|c|c|c|c|c|c|c|c|c|c|}
\hline \multicolumn{2}{|c|}{ Betula pollen outbreak dates } & \multicolumn{3}{|c|}{ Vitoria-Gasteiz } & \multicolumn{3}{|c|}{ Vielha } & \multicolumn{4}{|c|}{ Bellaterra (control-station) } \\
\hline Start & End & Peak & Pollen per episode & $\%$ API & Peak & Pollen per episode & $\%$ API & Peak & Pollen per episode & $\%$ API & S/NS \\
\hline $24 / 04 / 04$ & $27 / 04 / 04$ & 135 & 491 & $37 \%$ & 225 & 967 & $42 \%$ & 146 & 237 & $49 \%$ & $\mathrm{~S}$ \\
\hline $13 / 05 / 04$ & $19 / 05 / 04$ & 43 & 132 & $10 \%$ & 102 & 422 & $18 \%$ & 41 & 139 & $29 \%$ & $\mathrm{~S}$ \\
\hline $12 / 04 / 05$ & $14 / 04 / 05$ & 25 & 43 & $9 \%$ & 1 & 7 & $0 \%$ & 18 & 36 & $41 \%$ & $\mathrm{~S}$ \\
\hline $26 / 04 / 06$ & $28 / 04 / 06$ & 1 & 39 & $7 \%$ & 2 & 84 & $6 \%$ & 41 & 77 & $35 \%$ & NS \\
\hline $16 / 04 / 07$ & $22 / 04 / 07$ & 71 & 446 & $72 \%$ & 37 & 433 & $45 \%$ & 78 & 154 & $51 \%$ & S \\
\hline $24 / 04 / 08$ & $26 / 04 / 08$ & 11 & 81 & $15 \%$ & 293 & 838 & $39 \%$ & 21 & 32 & $35 \%$ & NS \\
\hline $22 / 04 / 09$ & $24 / 04 / 09$ & 28 & 109 & $33 \%$ & 205 & 326 & $17 \%$ & 41 & 62 & $35 \%$ & S \\
\hline $10 / 04 / 10$ & $11 / 04 / 10$ & 103 & 251 & $14 \%$ & 20 & 127 & $4 \%$ & 13 & 21 & $18 \%$ & $\mathrm{~S}$ \\
\hline $30 / 03 / 12$ & $02 / 04 / 12$ & 59 & 178 & $39 \%$ & 8 & 29 & $1 \%$ & 11 & 23 & $26 \%$ & $\mathrm{~S}$ \\
\hline $12 / 04 / 14$ & $16 / 04 / 14$ & 2 & 83 & $31 \%$ & 71 & 990 & $51 \%$ & 39 & 98 & $51 \%$ & NS \\
\hline
\end{tabular}

\subsection{Meteorological scenarios causing simultaneous birch pollen outbreaks}

The meteorological scenario giving rise to the transport of highly Betula pollen loaded air masses from France and Central Europe to the Iberian Peninsula is analysed by using sea level pressure maps and contour maps at 850 and $700 \mathrm{hPa}$ for the days with simultaneous peaks. Fig. 4 shows as the driving force causing the transport is due to the presence of a sea level high-pressure system and highs at 700 and $850 \mathrm{hPa}$ over S British Islands reinforced by two lows over Morocco at sea level and at $850 \mathrm{hPa}$ (Fig. 4a, b) and over S Iberian Peninsula at $700 \mathrm{hPa}$ (Fig. 4c). The transport from NE is well detected at the three levels.

\subsection{Mesoscale modelling. Study cases}

Back-trajectories were also computed with the WRF model in two study cases of LRT of Betula pollen: (1) the simultaneous Betula pollen peak episode recorded on the 26th of April 2004, and (2) the non-simultaneous peak episode detected on the 27th of April 2006.

\subsubsection{Study case 1: simultaneous LRT outbreak of birch pollen on the 26th of April 2004}

A significant increase of Betula daily airborne pollen concentrations was observed from the 25th to the 27th of April 2004 in the three sampling stations, reaching up to $145 \mathrm{pollen} / \mathrm{m}^{3}$ in the control-station Bellaterra, 135 pollen $/ \mathrm{m}^{3}$ in Vitoria-Gasteiz and 313 pollen $/ \mathrm{m}^{3}$ in Vielha (Fig. 5). The pollen sum recorded during this outbreak was 237, 491 and 967 pollen grains in Bellaterra, Vitoria-Gasteiz and Vielha, respectively (Table 2), which accounted for $37-49 \%$ of the API in 2004 (Table 2).

The synoptic situation during this episode (not shown) was characterized by a high-pressure system centered over Central Europe and low-pressure systems located over the Mediterranean. This resulted in a synoptic circulation with prevailing NE winds from Central Europe to the Iberian Peninsula. The 48-h back-trajectories calculated with WRF model at 100, 700 and $1500 \mathrm{~m}$ a.s.1. in D1 from the 24th of April 2004 at 00:00 UTC to the 26th of April 2004 at 00:00 UTC (Fig. 6a-c) showed that air masses approached $\mathrm{N}$ Iberian Peninsula after passing over France and central Europe, going around the Alps and Massif Central before they arrived at the Iberian Peninsula. The pathway drawn by 36-h WRF back-trajectory simulations in D3 at the same levels from the 24th of April 2004 at 12:00 UTC to the 26th of April 2004 at 00:00 UTC (Fig. 6d-f) allowed a more refined interpretation of the arrival of pollen to the study area. On the 26th of April
2004, pollen transported by NE air masses were channeled into the lowlands through western and eastern extremities of Pyrenees chain before arriving to Vitoria-Gasteiz and Bellaterra respectively (Fig. 6). Two different pathways were observed in the D3 for the eastern-most air flows before to attain Bellaterra: 1) in parallel to the coast in the Mediterranean Sea at 100 and $700 \mathrm{~m}$ a.s.l. (Fig. 6d, e), and 2) through the Alberes region (500 $\mathrm{m}$ a.s.1.) at $1500 \mathrm{~m}$ a.s.l. (Fig. 6f). Whereas Vielha station was directly impacted by air masses coming from France due to its location on the $\mathrm{N}$ side of the Pyrenees, open to France (Fig. 6). Particularly, WRF simulations in D3 showed that air masses travelled through the Garona valley before reaching up Vielha (Fig. 6d-f). A rise of daily Betula pollen concentrations was also registered during the previous days at five sampling stations from the French Aerobiology Network (RNSA; [accessed July 1, 2016], http://www.pollens.fr/en/) situated nearby to the pathway drawn by WRF back-trajectory simulations (Fig. 6), being 48 pollen $/ \mathrm{m}^{3}$ in Pau, 49 pollen $/ \mathrm{m}^{3}$ in Toulouse, 240 pollen $/ \mathrm{m}^{3}$ in Perpignan, 384 pollen $/ \mathrm{m}^{3}$ in Aurillac and 225 pollen $/ \mathrm{m}^{3}$ in Strasburg on the 24th of April 2004 (Fig. 5).

\subsubsection{Study case 2: non-simultaneous LRT outbreak of birch pollen on the 27th of April 2006}

Daily airborne pollen concentrations of Betula increased from 2 pollen $/ \mathrm{m}^{3}$ on the 25 th of April 2006 to 41 pollen $/ \mathrm{m}^{3}$ on the 27 th of April 2006 in the control-station Bellaterra, conversely a significant decrease was observed in the other two sampling stations, where the records resulted $\leq 2$ pollen $/ \mathrm{m}^{3}$ on the 27th of April 2006 (Fig. 7). However, the pollen sum registered during this episode was 77 pollen grains in Bellaterra, 88 in Vielha and 39 in Vitoria-Gasteiz, accounting for $35 \%, 6 \%$ and $7 \%$ of the 2006 API respectively (Table 2).

The synoptic situation during this episode (not shown) was typified by two high-pressure systems placed over Atlantic at SW of the British Isles and over the $\mathrm{S}$ of the Iberian Peninsula, and a low-pressure system over $\mathrm{N}$ Italy. According to this synoptic situation, WRF 48 h-back-trajectories at 700 and $1500 \mathrm{~m}$ a.s.l. in D1 from the 25th of April 2006 at 00:00 UTC to the 27th of April 2006 at 00:00 UTC (Fig. $8 \mathrm{a}-\mathrm{c}$ ) showed that the air mass flow came from the NW at the three sampling stations. However, back-trajectories at $100 \mathrm{~m}$ a.s.l. showed a similar NW influx that passed over the Atlantic before reaching Vitoria-Gasteiz and Vielha on the 27th of April 2006, while air fluxes incoming to Bellaterra came from France. Simulations in D3 showed detailed 36-h WRF back-trajectory at 100, 700 and 1500 m.a.s.l from 25th April 2006 at 12:00 UTC to the 27th of April 2006 at 00:00 UTC (Fig. 8d-f). Atlantic provenance observed in D1 (Fig. 8a-c) at Vitoria-Gasteiz was also observed in D3. However, pathways modelled by WRF in D3 in Vielha came from $\mathrm{S}$ France, 
a)

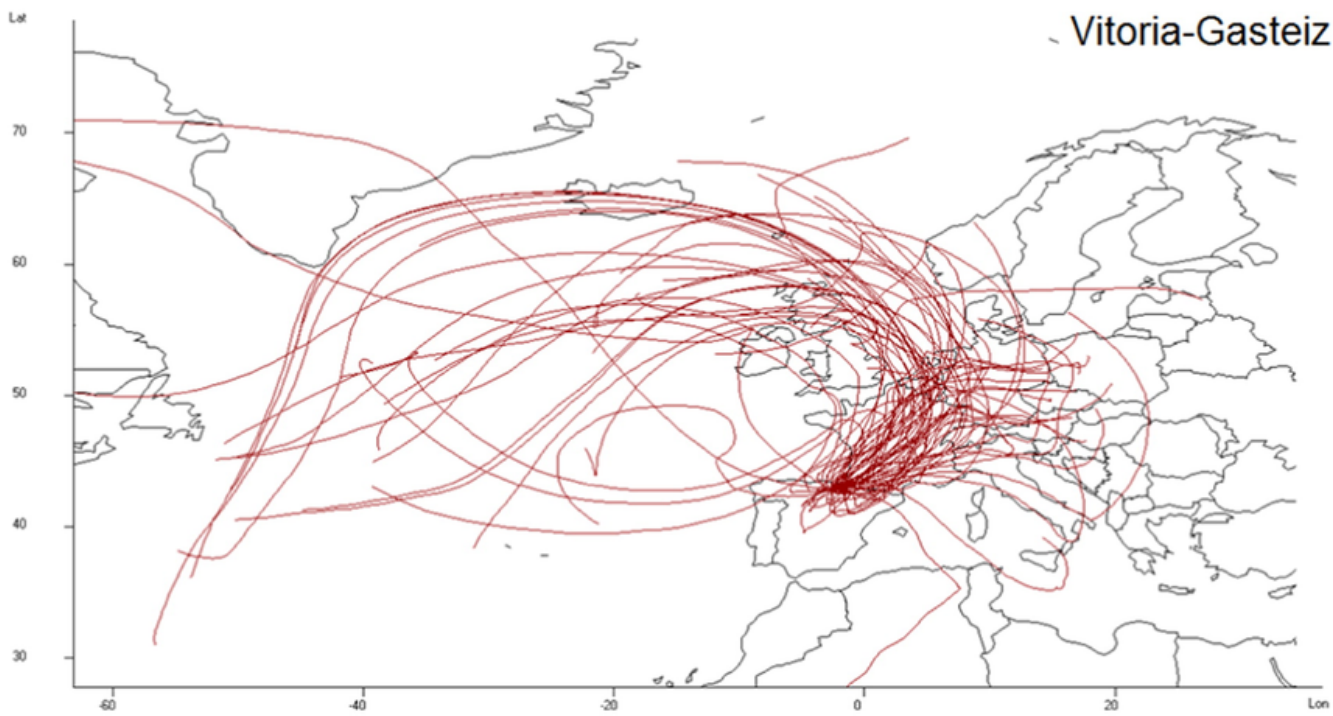

b)

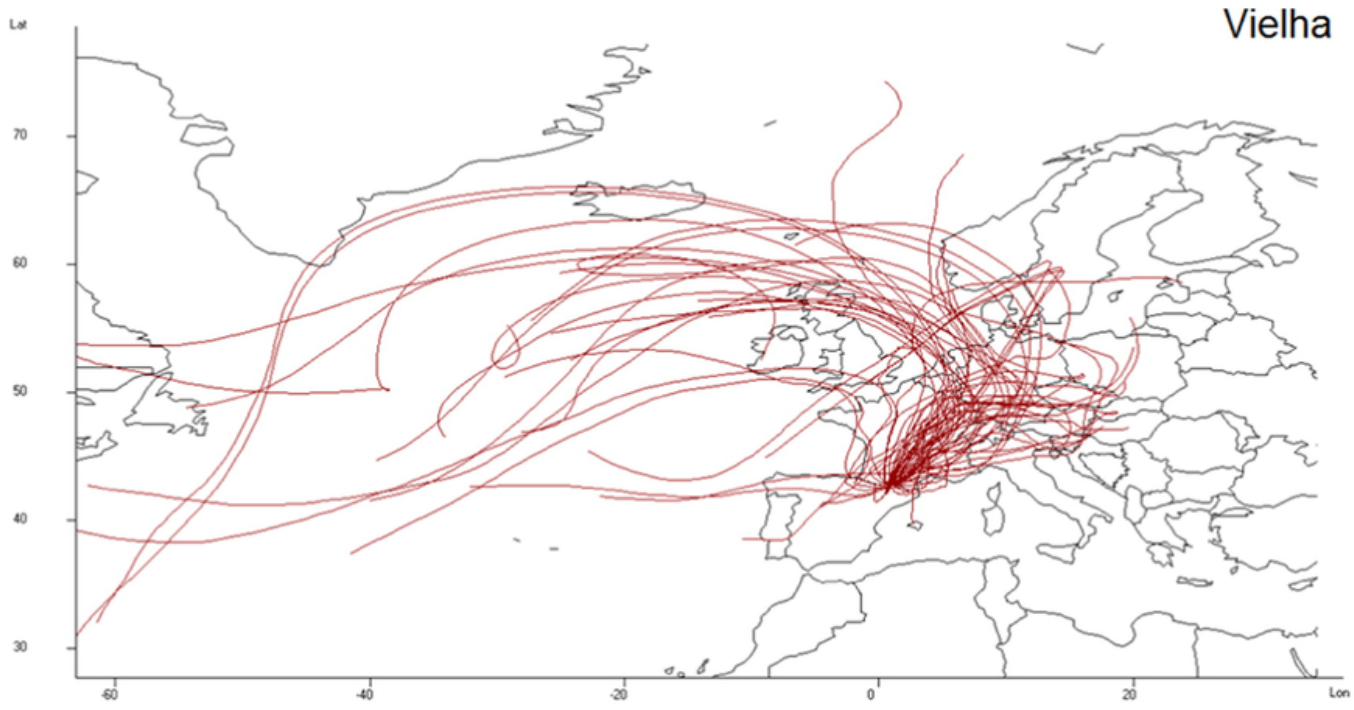

c) $w$

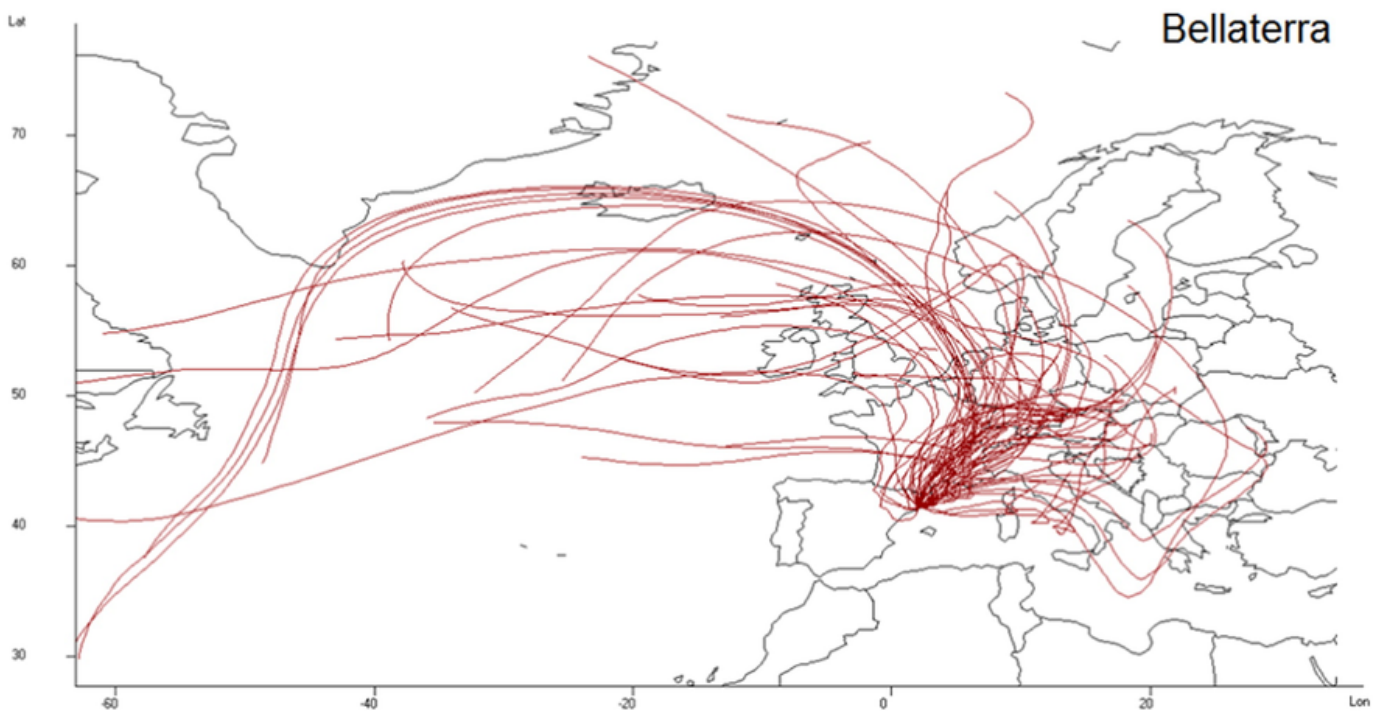




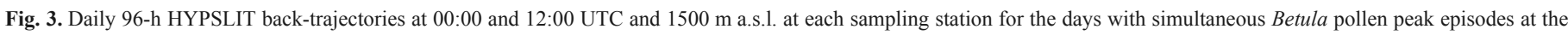
three sampling stations during the period 2004-2014: a) Vitoria-Gasteiz, b) Vielha, and c) Bellaterra.

a)

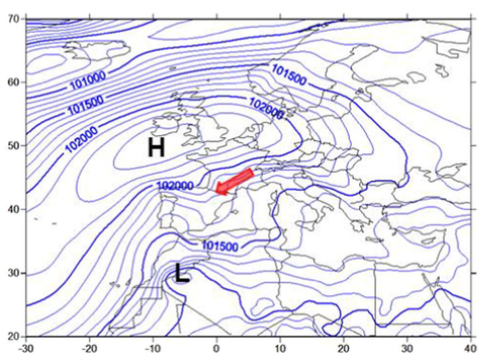

b)

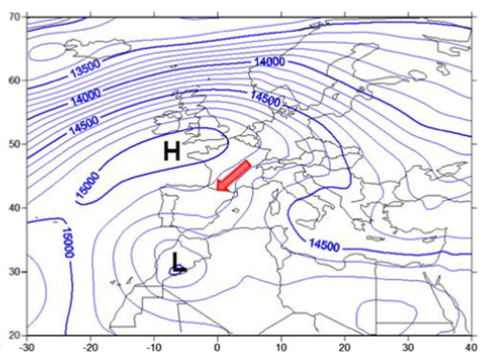

c)

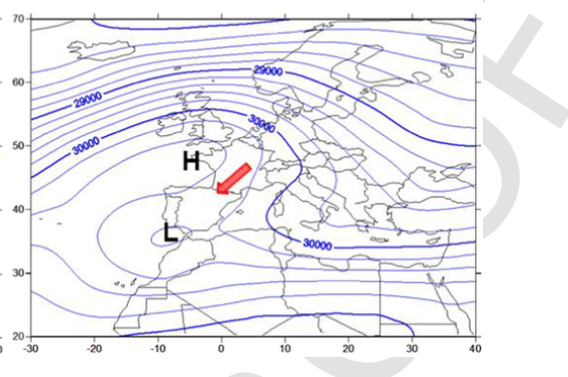

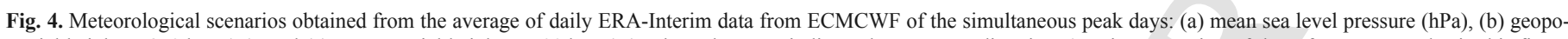

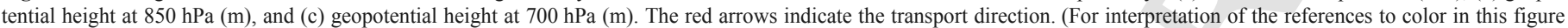
legend, the reader is referred to the web version of this article.)

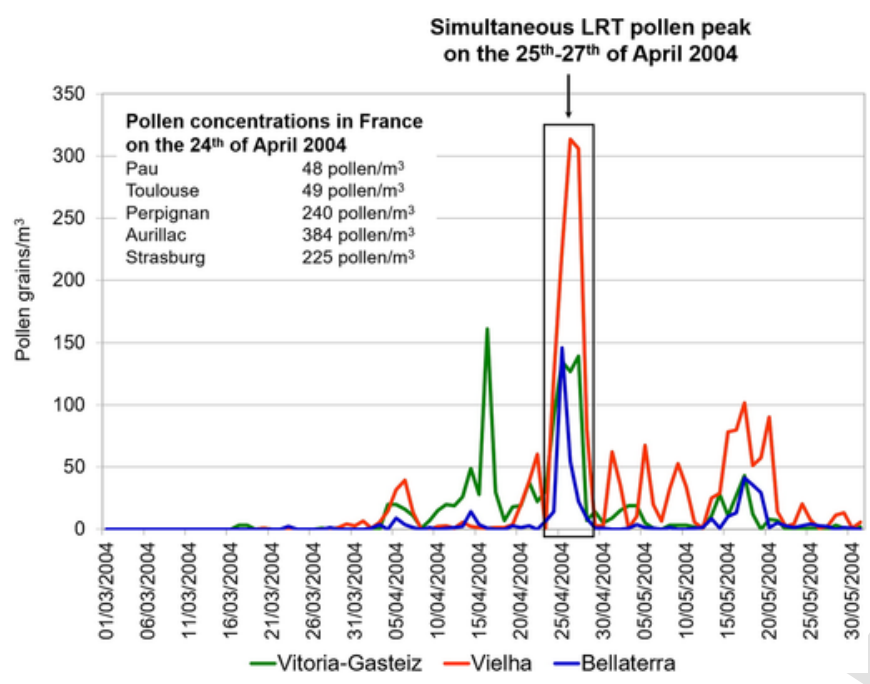

Fig. 5. Mean daily airborne Betula pollen concentrations (pollen grains $/ \mathrm{m}^{3}$ ) registered in: a) Vitoria-Gasteiz, Vielha and Bellaterra from the 1st of March to the 31st of May 2004; b) five sampling stations from the French Aerobiology Network (RNSA; [accessed July 1, 2016], http://www.pollens.fr/en/) on the day previous to the non-simultaneous LRT pollen peak episode. RNSA stations were selected in terms of their location close to the pathway drawn by the WRF back-trajectory simulations that arrived to the study site on the 26th of April 2004.

showing different provenance than in D1, but revealing in the short length and curved shape of their trajectories a more local/regional origin, prevailing over the LRT that would explain the low pollen load. Finally, a consistent flow coming from the region of the French Alps across the Mediterranean coast of France was identified in D1 and D3 at $100 \mathrm{~m}$ a.s.1. for Bellaterra (Fig. 8a, d). Conversely, WRF back-trajectories in both domains at 700 and $1500 \mathrm{~m}$ a.s.l. were originated in S France and passed through the eastern-most Pyrenean extreme at the Alberes region before reaching up Bellaterra (Fig. 8b-f). Besides, daily Betula pollen concentrations registered on the 26th of April 2006 at five RNSA sampling stations situated nearby to the pathway drawn by the WRF back-trajectory simulations (Fig. 8), showed higher values in Montpellier and Aurillac, accounting for 154 pollen/ $\mathrm{m}^{3}$ and 864 pollen $/ \mathrm{m}^{3}$ respectively, than in Pau, Toulouse and Perpignan, which ranged between 2 and 17 pollen $/ \mathrm{m}^{3}$ (Fig. 7).

\subsection{Source-receptor model}

Concentration maps of Betula pollen derived from the source-receptor model applied to the complete set of daily pollen data from the 1st of March to the 30th of May for 2004-2014 period suggested that France and central Europe were the most likely source areas for the stations placed at extremities of Pyrenees, concretely: N France for Vitoria-Gasteiz (Fig. 9a) and Switzerland for Bellaterra (Fig. 9c). In contrast, distant source-areas were not identified by the source-receptor model in Vielha for this dataset (Fig. 9b) due to the high influence of local sources.

Source-receptor model results obtained for the days with simultaneous Betula pollen peak showed that probable source-areas were: (1) SW France for Vitoria-Gasteiz (Fig. 9d); (2) Central and SW France for Vielha (Fig. 9e); and (3) Mediterranean coast of France and Switzerland for Bellaterra (Fig. 9f).

\section{Discussion}

The high temporal and spatial variability of the Betula pollen dynamics observed at the three sampling stations (Table 1) were also noticed in previous studies carried out in NW Spain (Jato et al., 2002; Méndez et al., 2005). These fluctuations have been related to several factors: (1) the location of each sampling station and the spatial distribution of Betula trees (Fig. 1; De Bolòs et al., 1990; Beck et al., 2016); (2) year-to-year variations of local/regional environmental drivers that control the timing of flowering and the release processes of pollen (Jato et al., 2002); and (3) specific synoptic scale weather systems that affect the phenological stages over a region and also determine the transport of the emitted pollen grains from adjacent and remote regions (Veriankaite et al., 2010). According to these factors, API of Betula (Table 1) showed that Vielha was the station that was the most influenced by local sources, followed by Vitoria-Gasteiz. Since contributions of local pollen sources complicated the reliable identification of the long-range episodes, Bellaterra was chosen as control-station as it had the lowest influence of local Betula pollen sources.

In accordance with Skjøth et al. (2009), results showed that $B e$ tula pollen amounts recorded during a single episode represented the $18-77 \%$ of the API in the control-station Bellaterra (Table 2), which indicates that Betula pollen originated outside of our study area could make a notable contribution to the airborne catch in the three sam- 
a)

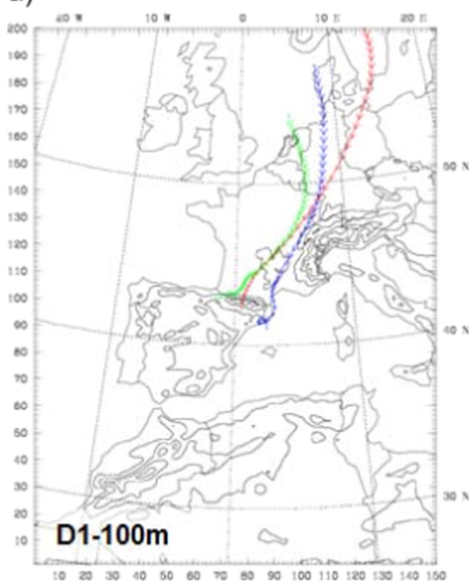

d)

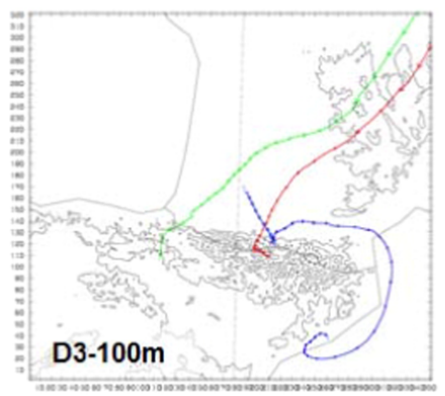

b)

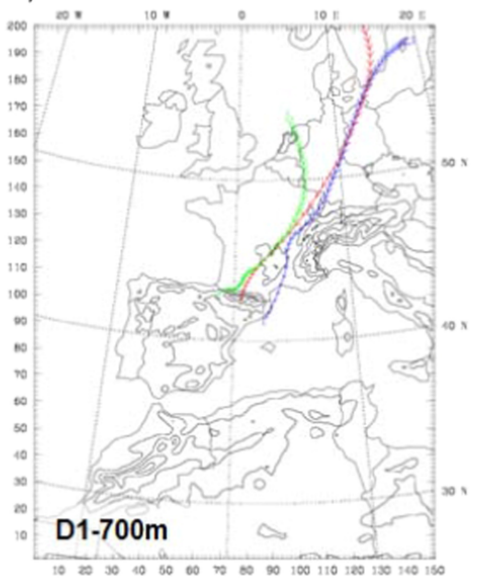

e)

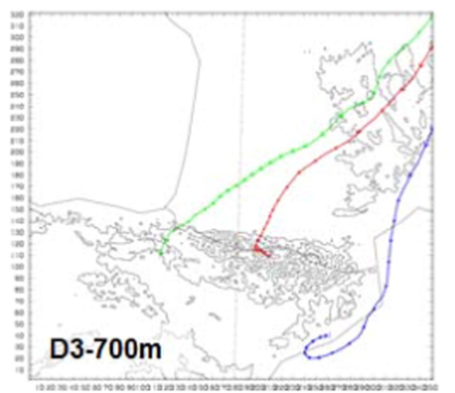

c)

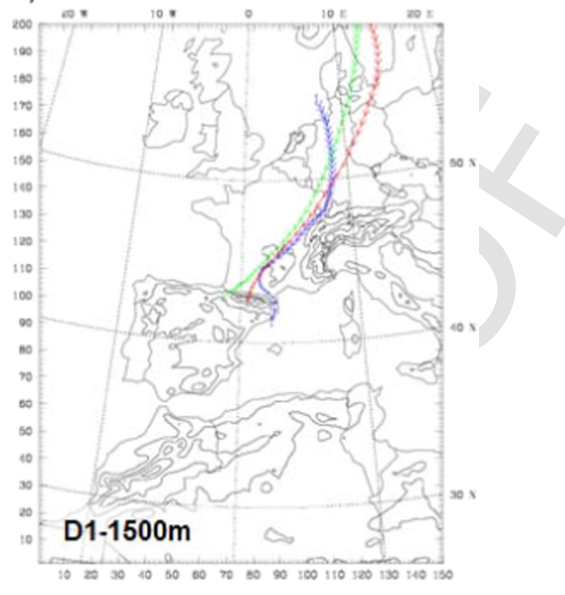

f)

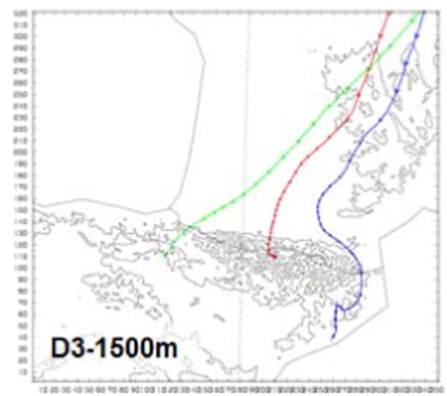

Fig. 6. WRF back-trajectories at 100, 700 and $1500 \mathrm{~m}$ a.s.l. arriving on the 26th of April 2004 at 00:00 UTC $48 \mathrm{~h}$ length for domain 1 (a, b, c) and $36 \mathrm{~h}$ length for domain 3 (d, e, f) at the three sampling stations.

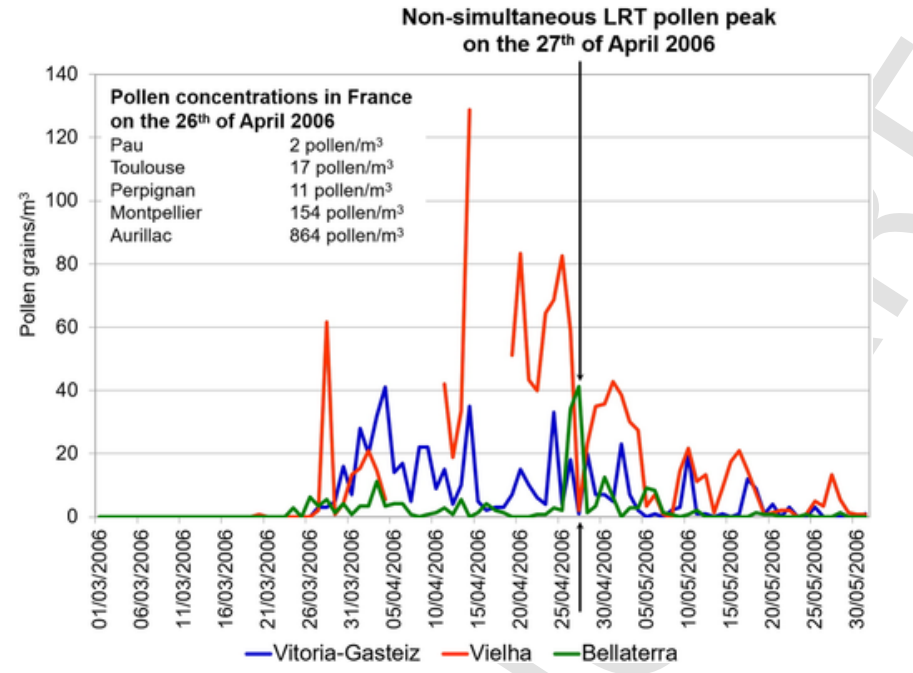

Fig. 7. Mean daily airborne Betula pollen concentrations (pollen grains $/ \mathrm{m}^{3}$ ) registered in: a) Vitoria-Gasteiz, Vielha and Bellaterra from the 1st of March to the 31st of May 2006 (discontinuity in the time serie of Vielha corresponds to missing data); b) five sampling stations from the French Aerobiology Network (RNSA; [accessed July 1, 2016], http://www.pollens.fr/en/) on the day previous to the non-simultaneous LRT pollen peak episode. RNSA stations were selected in terms of their location close to the pathway drawn by the WRF back-trajectory simulations that arrived to the study site on the 27th of April 2006.

pling stations during the main birch pollen season. Seven LRT Betula pollen outbreak episodes were registered simultaneously at the three sampling stations and three exclusively at the Bellaterra control-sta- tion during the study period. Betula pollen values recorded at the control-station Bellaterra during seven of these LRT pollen outbreaks were higher than 30 pollen $/ \mathrm{m}^{3}$, which is the quantity considered sufficient to trigger severe allergy symptoms (Corsico, 1993; Cotos-Yáñez et al., 2004). In the same way, in the study case 1, pollen peaks increased drastically over 80 pollen $/ \mathrm{m}^{3}$, which is the value cited as sufficient to produce symptoms in $90 \%$ of the patients (Viander and Koivikko, 1978; Detandt and Nolard, 1996), reaching up to 146 pollen $/ \mathrm{m}^{3}$ in the control-station Bellaterra, 135 pollen $/ \mathrm{m}^{3}$ in Vitoria-Gasteiz and 313 pollen $/ \mathrm{m}^{3}$ in Vielha (Fig. 5). These results brought to light the potential allergenic impact of LRT of Betula pollen outbreaks over N Iberian Peninsula, even in Bellaterra where the plant is scarcely present (only for ornamental purposes) and the population with respiratory allergy is not used to being exposed to this pollen. Clinicians should take this pollen type into consideration in certain cases where the etiology of the allergy is not explained by common pollen and spore types.

Back-trajectories have been used to infer the atmospheric pathways of the air masses reaching the stations during these particular days. Previous research showed that even when series of trajectories are used to account for uncertainty, the air masses usually arrive from a relatively confined region (Skjøth et al., 2007). Different atmospheric pathways have been identified during the simultaneous pollen peak episodes. Back-trajectories that arrived at Vitoria-Gasteiz had a westerly path forming an Atlantic arc over W France, while back-trajectories incoming to Vielha and Bellaterra crossed over the Mediterranean coast of France (Fig. 3). The atmospheric routes detected by back-trajectories have been related with the meteorological scenario characterized by the presence of high-pressure systems over S British 
a)

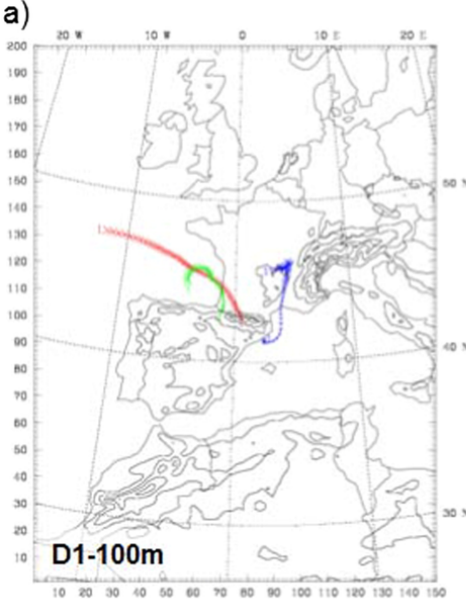

d)

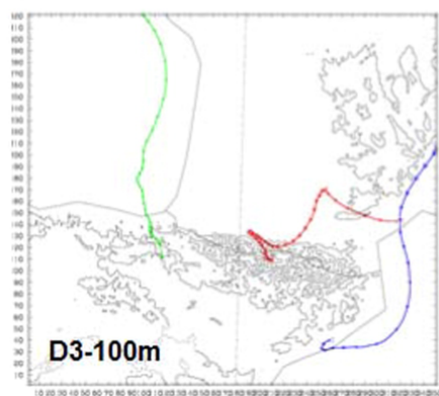

b)

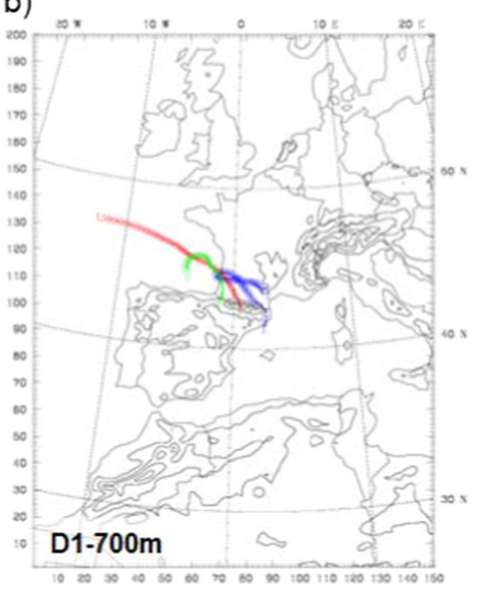

e)

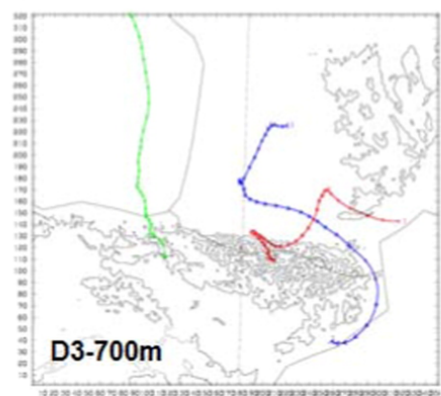

c)

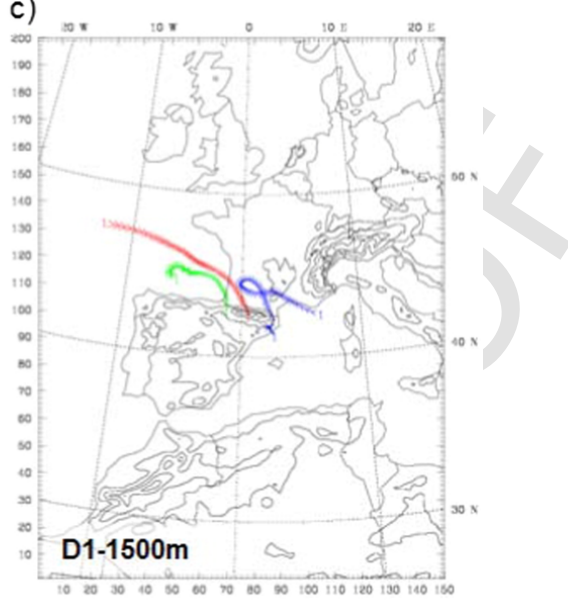

f)

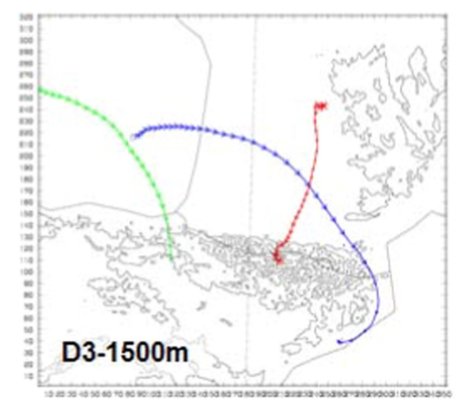

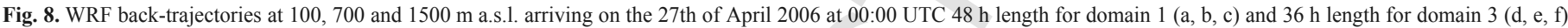
at the three sampling stations.

a)

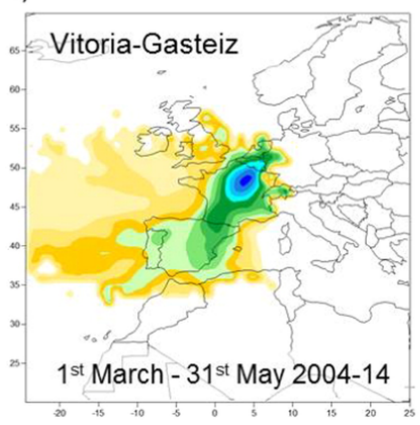

d)

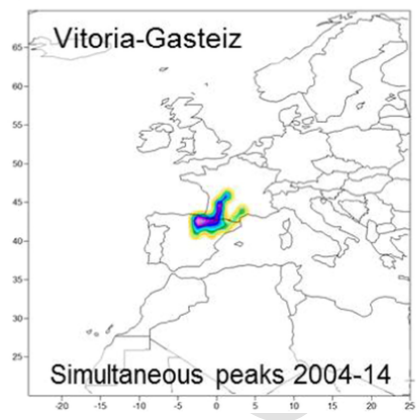

b)

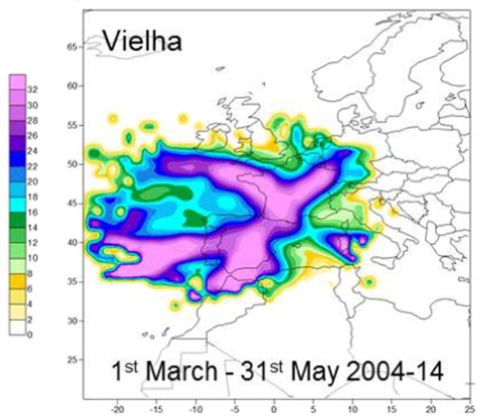

e)

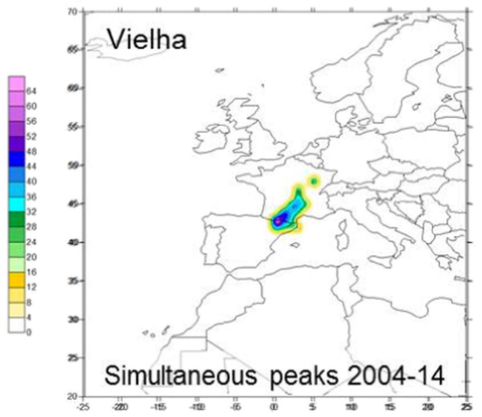

c)

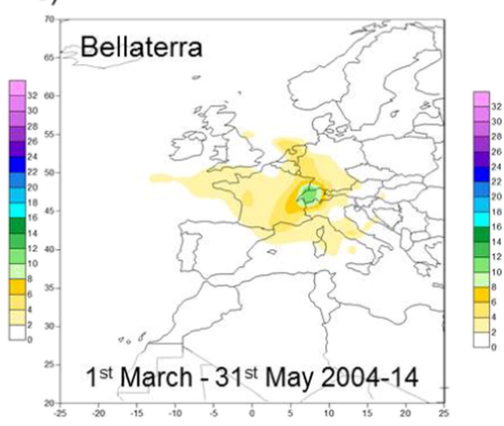

f)

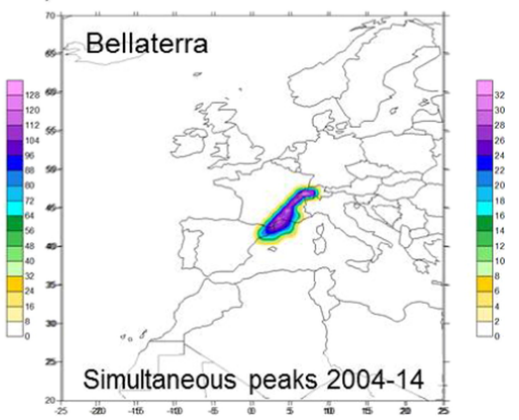

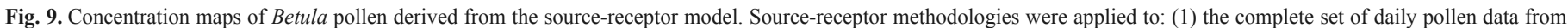

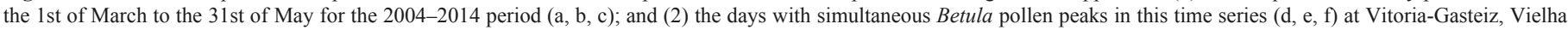
and Bellaterra. Pollen concentration levels ranged between $0-32$ pollen $/ \mathrm{m}^{3}$ in all figures, except in panels $\mathrm{d}\left(0-64 \mathrm{pollen} / \mathrm{m}^{3}\right)$ and e $\left(0-128\right.$ pollen $\left./ \mathrm{m}^{3}\right)$. 
Islands at sea level, 850 and $700 \mathrm{hPa}$ reinforced by low-pressure systems over Morocco at sea level and at $850 \mathrm{hPa}$ (Fig. 4a,b) and over S Iberian Peninsula at $700 \mathrm{hPa}$ (Fig. 4c).

Specific episodes modelled by WRF model exhibited the effect of the orography on the atmospheric transport patterns. Specifically, in the simultaneous pollen outbreak registered on the 26th of April 2004 (case study 1, Fig. 5), atmospheric pathways for the three sampling stations were similar in D1, going around the Alps and Massif Central before arriving to the Iberian Peninsula (Fig. 6a-c). However, when air masses coming from France arrived to the Pyrenees, they crossed through western and eastern extremities of the chain to reach Vitoria-Gasteiz and Bellaterra respectively, and impacted directly over Vielha through the Garona valley (Fig. 6). These results support the argument that LRT of pollen from Europe to the Iberian Peninsula is a broad-scale phenomenon, being able to cross the Pyrenees when wind is channeled through specific regions, as Les Alberes region and the Garona Valley. This outcome is backed up by increase of Betula pollen concentrations observed in the RNSA stations located nearby to the WRF back trajectories pathway in France on the 24th of April (Fig. 5). Both pathways observed in the D3 for the eastern-most air flows before to reaching up Bellaterra are in concordance with the RNSA data. The path through the Mediterranean Sea could be related with the sea breeze influence, which is relevant in the Iberian Mediterranean coastal regions, especially in spring and summer. Besides, the sea breeze is stronger in the Barcelona area, where the Bellaterra station is located, because of the development of the upslope winds on the southern slopes of the coastal mountain range, which contribute to the reinforcement of the general onshore flow (Barros et al., 2003) and the production of Betula peaks when these air-masses are pollen loaded. The path through Les Alberes region pass was also traced by the MM5 mesoscale model to describe the LRT transport of Fagus pollen from NE France and SW Germany to Catalonia (Belmonte et al., 2008).

Allergenic LRT Betula pollen outbreaks could also occur affecting only a particular sampling station, as it has been observed during the non-simultaneous episode registered on the 27th of April 2006 (case study 2, Fig. 7). During this episode, a consistent flow loading Betula pollen from France crossed over the easternmost impacting only the control-station Bellaterra (Fig. 8). According with the high pollen concentrations observed on the 26th of April 2006 in Aurillac and Montpellier in front the low values recorded in Toulouse and Perpignan, the most likely pathway for pollen transport was the air flow coming from the region of the French Alps across the Mediterranean coast of France reaching up Bellaterra through the Mediterranean Sea (Fig. 8a, d).

Similarly to the meteorological modelling results, source areas identified by the source-receptor model were located westerly for Vitoria-Gasteiz and displaced through the Mediterranean coast for Bellaterra (Fig. 9). During the main pollen season, France and Central Europe have been established as source areas of Betula pollen in Vitoria-Gasteiz and Bellaterra, in particular N France (Fig. 9a) and Switzerland (Fig. 9c), respectively. These results are in accordance with the distribution and abundance of Betula trees (Fig. 1), as well as the high mean APIs of Betula recorded by RNSA during the 2004-2014 period in the proposed source areas, accounting for 3885 pollen grains in Paris and 3833 in Strasburg. Source-receptor model for the days with simultaneous Betula pollen peaks suggested also a west-to-east geographical location of source regions depending on the sampling station, being the probable source areas: the SW France for Vitoria-Gasteiz (Fig. 9d); Central and SE France for Vielha (Fig. 9e), and the Mediterranean coast of France and E Switzerland for Bellaterra (Fig. 9f). The high mean APIs of Betula for the 2004-2014 pe- riod detected in the RNSA stations of Pau (2304 pollen grains) and Aurillac ( 5770 pollen grains) support the source areas identified by the source receptor model in SW and Central France. Conversely, the low mean APIs of Betula registered during the study period in Perpignan (446 pollen grains) and Montpellier (749 pollen grains) in front to the higher values observed in Grenoble (2296 pollen grains) and Strasburg (3833 pollen grains) point out that E France and E Switzerland were the probable source areas of Betula pollen for Bellaterra. Betula forest distribution also supported the hypothesis that discard the Mediterranean coast as source area for Bellaterra.

\section{Conclusion}

The current study supports the hypothesis that LRT of pollen from Europe and Iberian Peninsula could be a broad-scale phenomenon, being able to cross over the Pyrenees and to produce allergic diseases under specific meteorological situations that favours the atmospheric transport when wind is channeled through regions as Les Alberes and the Garona Valley. Taking into account birch forests distribution and the RNSA pollen records, France and Central Europe have been established as potential source areas of Betula pollen that arrives to $\mathrm{N}$ Spain, however the specific source areas are mainly determined by the particular prevailing atmospheric circulation of each location. Both meteorological modelling and source-receptor model showed different atmospheric pathways and specific source regions according to the geographical situation of the sampling stations, particularly they came from the west, forming an Atlantic arc over W France, for Vitoria-Gasteiz and moved through the Mediterranean region for Bellaterra. Additionally, WRF model highlighted the effect of the orography on the atmospheric transport patterns, showing paths through the western and easternmost lowlands for Vitoria-Gasteiz and Bellaterra respectively, and the direct impact of airflows on Vielha through the Garona valley. Betula pollen outbreaks have been associated to the presence of high-pressure systems located over S British Islands reinforced by low-pressure systems over NW Africa and S Iberian Peninsula. Despite more research is needed to better forecast the timing and severity of these potential allergenic outbreaks, the meteorological scenario identified in this study could be used as first approximation to predict the possible arrival of Betula pollen to N Spain during the flowering season with the aim to give advance warning for the allergenic population.

\section{Acknowledgements}

We acknowledge the financial support from European Commission for "ENV4-CT98-0755"; the Spanish Government for "AMB97-0457-CO7-021", "REN2001-10659-CO3-01", "CGL2004-21166-E”, “CGL2005-07543/CLI", “CGL2009-11205”, "CGL2012-39523-C02-01/CLI", CGL2012-39523-C02-02, CGL2012-37416-C04-03, and CONSOLIDER GRACCIE; the Catalan Government AGAUR for "2002SGR00059”, “2005SGR00519”, "2009SGR1102" and "2014SGR1274" and the several institutions and companies making possible the aerobiological databases with their contracts and donations. This work is contributing to the ICTA 'Unit of Excellence' (MinECo, MDM2015-0552). The authors thank the French Aerobiology Network (RNSA) for the aerobiological data.

\section{References}

Aira, M.J., Ferreiro, M., Iglesias, I., Jato, V., Marcos, C., Varela, S., Vidal, C., 2001 Aeropalinologia de cuatro ciudades de Galicia y su incidencia sobre la sintomatología alérgica estacional. In: Renduelles, B., Moreno, J. (Eds.), Moreno E. Pro- 
ceedings of the XIII Simposio de la A.P.L.E. University of Cartagena, Cartagena, Spain, pp. 105-114.

Artz, R., Pielke, R.A., Galloway, J., 1985. Comparison of the ARL/ATAD constant level and the NCAR isentropic trajectory analices for selected case studies. Atmos. Environ. 19, 47-63.

Ashbaugh, L.L., 1983. A statistical trajectory technique for determining air pollution source regions. J. Air Pollut. Control Assess. 33, 1096-1098.

Barros, N., Borrego, C., Toll, I., Soriano, C., Jiménez, P., Baldasano, J.M., 2003. J. Air Waste Manag. Assoc. 53, 347-359.

Beck, P., Caudullo, G., de Rigo, D., Tinner, W., 2016. Betula pendula, Betula pubescens and other birches in Europe: distribution, habitat, usage and threats. In San-Miguel-Ayanz, J., de Rigo, D., Caudullo, G., Houston Durrant, T., Mauri, A. (Eds.), European Atlas of Forest Tree Species. Publication Office of the European Union. pp. 70-73.

Begum, B.A., Kim, E., Jeong, C., Lee, D., Hopke, P.K., 2005. Evaluation of the potential source contribution function using the 2002 Quebec forest fire episode. Atmos. Environ. 39, 3719-3724

Belmonte, J., Vendrell, M., Roure, J.M., Vidal, J., Botey, J., Cadahía, A., 2000. Levels of Ambrosia pollen in the atmospheric spetra of catalan aerobiological stations. Aerobiologia 16, 93-99.

Belmonte, J., Alarcón, M., Avila, A., Scialabba, E., Pino, D., 2008. Long-range transport of beech (Fagus sylvatica L.) pollen to Catalonia (north-eastern Spain). Int. J. Biometeorol. 52, 675-687.

Burczyk, J., DiFazio, S.P., Adans, W.T., 2004. Gene flow in forest trees: how far do genes really travel?. For. Genet. 11, 1-14.

Charron, A., Plaisance, H., Sauvage, S., Coddeville, P., Galloo, J.C., Guillermo, R., 2000. A study of the source-receptor relationships influencing the acidity of precipitation collected at a rural site in France. Atmos. Environ. 34, 3665-3674.

Chen, F., Dudhia, J., 2001. Coupling and advanced land surface hydrology model with the Penn State-CAR MM5 modeling system: part I: model implementation and sensitivity. Mon. Weather Rev. 129, 569-585.

Corsico, R., 1993. L'asthme allergique en Europe. In: Spieksma, F.T.M., Nolard, N., Frenguelli, G., Van Moerbeke, D. (Eds.), Pollens de l'air en Europe. UCB, Braine-l'Alleud pp, pp. 19-29.

Cotos-Yáñez, T.R., Rodríguez-Rajo, F.J., Jato, M.V., 2004. Short-term prediction of Betula airborne pollen concentration in Vigo (NW Spain) using logistic additive models and partially linear models. Int. J. Biometeorol. 48, 179-185.

D'Amato, G., Cecchi, L., Bonini, S., Nunes, C., Annesi-Maesano, I., Behrendt, H., Liccardi, G., Popov, T., van Cauwenbergh, P., 2007. Allergenic pollen and pollen allergy in Europe. Allergy 62, 976-990.

Dayan, U., Lamb, D., 2003. Meteorological indicators of summer precipitation chemistry in central Pennsylvania. Atmos. Environ. 37, 1045-1055.

De Bolòs, O., Vigo, J., Masalles, R.M., Ninot, J.M., 1990. Flora manual dels països Catalans. Pòrtic SA, Editorial, 1-1310.

Detandt, M., Nolard, N., 1996. The Belgian pollen service: immediate and direct infor mation to hay fever sufferers. Aerobiologia 12, 197-200.

Dopazo, A., 2001. Variación estacional y modelos predictivos de polen y esporas aeroalergénicos en Santiago de Compostela. Universidad de Santiago de Compostela, Tesis Doctoral

Draxler, R.R., Rolph, G.D., 2003. HYSPLIT (HYbrid Single-Particle Lagrangian Integrated Trajectory) Model access via NOAA ARL READY website. In: (http:/ www.arl.noaa.gov/ready/hysplit4.html) (NOAA Air Resources Laboratory, Silver Spring, MD)

Dudhia, M., 1989. Numerical study of convection observed during the winter monsoon experiment using a mesoscale two-dimensional model. J. Atmos. Sci. 46, 3077-3107.

Ellstrand, N.C., 1992. Gene flow by pollen: implications for plant conservations genetics. Oikos 63, 77-86.

Emberlin, J., Savage, M., Woodman, R., 1993. Annual variation in Betula pollen seasons in London 1961-1990. Grana 32, 359-363.

Emberlin, J., Mullins, J., Corden, J., Millington, W., Brooke, M., Savage, M., Jones, S., 1997. The trend to earlier birch pollen season in the UK, a biotic response to change in weather conditions?. Grana 36, 29-33.

Ennos, R.A., 1994. Estimating the relative rates of pollen and seed migration among plant populations. Heredity 72, 250-259.

Fernández-Llamazares, A., Belmonte, J., Delgado, R., De Linares, C., 2014. A statistical approach to bioclimatic trend detection in the airborne pollen records of Catalonia (NE Spain). Int. J. Biometeorol. 58, 371-382.

Galán Soldevilla, C., Cariñanos González, P., Alcázar Teno, P., Domínguez Vilches, E., 2007. Manual de Calidad y Gestión de la Red Española de Aerobiología. Servicio de Publicaciones, Universidad de Córdoba.

Haran, J., Roques, A., Bernard, A., Robinet, C., Roux, G., 2015. Altitudinal barrier to the spread of an invasive species: could the Pyrenean chain slow the natural spread of the pinewood nematode?. PLoS One 10 (7), e0134126.

Heinzerling, L.M., Burbach, G.J., Edenharter, G., Bachert, C., Bindslev-Jensen, C., Bonini, S., Bousquet, J., Bousquet-Rouanet, L., Bousquet, P.J., Bresciani, M., et al., 2009. GA2LEN skin test study I: GA²LEN harmonization of skin prick testing: novel sensitization patterns for inhalant allergens in Europe. Allergy 64, 1498-1506.

Hirst, J.M., 1952. An automatic volumetric spore trap. Ann. Appl. Biol. 39, 257-265.

Hoh, E., Hites, R.A., 2004. Sources of toxaphene and other organochlorine pesticides in North America as determined by air measurements and potential source contribution function analyses. Environ. Sci. Technol. 38, 4187-4194.

Hong, S.Y., Pan, H.L., 1996. Nonlocal boundary layer vertical diffusion in a medium-range forecast model. Mon. Weather Rev. 124, 2322-2339.

Hong, S.Y., Dudhia, J., Chen, S., 2004. A revised approach to ice microphysical processes for the bulk parameterization of clouds and precipitation. Mon. Weather Rev. 132, 103-120.

Izquierdo, R., Belmonte, J., Àvila, A., Alarcón, M., Cuevas, E., Alonso-Pérez, S., 2011. Source areas and long-range transport of pollen from continental land to Tenerife (Canary Islands). Int. J. Biometeorol. 55, 67-85.

Izquierdo, R., Aguillaume, L., Alarcón, M., Avila, A., 2014. Effects of teleconnection patterns on the atmospheric routes, precipitation amount and chemistry in the north-eastern Iberian Peninsula. Atmos. Environ. 89, 482-490.

Janjic, Z.I., 1996. Nonsingular Implementation of the Mellor-Yamada Level 2.5 Scheme in the NCEP Meso model. NCEP Office Note No. 437, 61.

Janjic, Z.I., 1996. The surface layer in the NCEP Eta Model. Eleventh Conference on Numerical Weather Prediction, Norfolk, VA, 19-23 August 1996, American Meteorological Society, Boston, MA, 354-355.

Jato, V., Aira, M.J., Iglesias, M.I., Alcázar, P., Cervigón, P., Fernández, D., Recio, M., Ruíz, L., Sbai, L., 1999. Aeropalynology of birch (Betula sp.) in Spain. Polen 10, 37-47.

Jato, V., Méndez, J., Rodríguez-Rajo, J., Seijo, C., 2002. The relationship between the flowering phenophase and airborne pollen of Betula in Galicia (N.W. Spain). Aerobiologia 18, 55-64.

Karrer, G., Skjøth, C.A., Šikoparija, B., Smith, M., Berger, U., Essl, F., 2015. Ragweed (Ambrosia) pollen source inventory for Austria. Sci. Total Environ. $523,120-128$

Mahura, A., Korsholm, U., Baklanov, A., Rasmussen, A., 2007. Elevated birch pollen episodes in Denmark: contributions from remote sources. Aerobiologia $23,171-179$

Méndez, J., Comtois, P., Iglesias, I., 2005. Betula pollen: one of the most important aeroallergens in Ourense, Spain. Aerobiological studies from 1993 to 2000. Aerobiologia 21, 115-124.

Mlawer, E.J., Taubman, S.J., Brown, P.D., Iacono, M.J., Clough, S.A., 1997. Radiative transfer for inhomogeneous atmospheres: RRTM, a validated correlated-k model for the longwave. J. Geophys. Res. 102, 663-682.

Müller-Germann, I., Vogel, B., Vogel, H., Pauling, A., Fröhlich-Nowoisky, J., Pöschl, U., Després, V.R., 2015. Quantitative DNA analyses for airborne birch pollen. PLoS One http://dx.doi.org/10.1371/journal.pone.0140949.

Pereira, C., Valero, A., Loureiro, C., Dávila, I., Martinez-Cócera, C., Murio, C., Rico, P., Palomino, R., 2006. Iberian study of aeroallergens sensitisation in allergic rhinitis. Eur. Ann. Allergy Clin. Immunol. 38, 186-194.

Piotrowska, K., 2008. Pollen production in selected species of anemophilous plants. Acta Agrobot. 61 (1), 41-52.

Polissar, A.V., Hopke, P.K., Harris, J.M., 2001. Source regions for atmospheric aerosol measured at Barrow. Alaska. Environ. Sci. Technol. 35, 4214-4226.

Ranta, H., Hokkanen, T., Linkosalo, T., Laukkanen, L., Bondestam, K., Oksanen, A., 2008. Male flowering of birch: spatial synchronization, year-to-year variation and relation of catkin numbers and airborne pollen counts. For. Ecol. Manag. 255, 643-650.

Salvador, P., Artiñano, B., Alonso, D.G., Querol, X., Alastuey, A., 2004. Identification and characterisation of sources of $\mathrm{PM}_{10}$ in Madrid (Spain) by statistical methods. Atmos. Environ. 38, 435-447.

Schmidt-Lebuhn, A.N., Seltmann, P., Kessler, M., 2007. Consequences of the pollination system on genetic structure and patterns of species distribution in the Andean genus Polylepis (Rosaceae): a comparative study. Pl. Syst. Evol. 266, 91-103.

Schmitt, T., 2009. Biogeographical and evolutionary importance of the European high mountain systems. Front. Zool. 6, 9 .

Seibert, P., Kromp-Kolb, H., Balterpensger, U., Jost, D.T., Schwikowski, M., Kasper, A., Puxbaum, H., 1994. Trajectory analysis of aerosol measurements at high alpine sites. In: Borrell, P.M.P., Cvitas, T., Seiler, W. (Eds.), Transport and Transformation of Pollutants in the Troposphere. Academic Publishing, Den Haag, pp. 689-693.

Sharma, C.M., Khanduri, V.P., 2007. Pollen-mediated gene flow in Himalayan long needle pine (Pinus roxburghii Sargent). Aerobiologia 23, 153-158.

Siljamo, P., Sofiev, M., Severova, E., Ranta, H., Kukkonen, J., Polevova, S., Kubin, E., Minin, A., 2008. Sources, impact and exchange of early spring birch pollen in the Moscow region and Finland. Aerobiologia 24, 211-230.

Skamarock, W.C., Klemp, J.B., Dudhia, J., Gill, D.O., Barker, D.M., Duda, M.G., Huang, X.Y., Wang, W., Powers, J.G., 2008. A Description of the Advanced Research WRF Version 3. NCAR Tech. Note NCAR/TN-4751STR, 2005. 
Skjøth, C.A., Hertel, O., Ellermann, T., 2002. Use of the ACDEP trajectory model in the Danish nation-wide background monitoring programme. Phys. Chem. Earth A B C 27 (35), 1469-1477.

Skjøth, C.A., Sommer, J., Stach, A., Smith, M., Brandt, J., 2007. The long range transport of birch (Betula) pollen from Poland and Germany causes significant pre-season concentrations in Denmark. Clin. Exp. Allergy 37, 1204-1212.

Skjøth, C.A., Smith, M., Brandt, J., Emberlin, J., 2009. Are the birch trees in southern England a source of Betula pollen for North London?. Int. J. Biometeorol. 53 (1), 75-86.

Skjøth, C.A., Baker, P., Sadyś, M., Adams-Groom, B., 2015. Pollen from alder (Alnus sp.), birch (Betula sp.) and oak (Quercus sp.) in the UK originate from small woodlands. Urban Climate 14, 414-428.

Smouse, P., Dyer, R.J., Westfall, R.D., Sork, V.L., 2001. Two-generation analysis of pollen flow across a landscape. I. Male gamete heterogeneity among females. Evolution 55, 260-271.

Sofiev, M., Siljamo, P., Ranta, H., Rantio-Lehtimaki, A., 2006. Towards numerical forecasting of long-range air transport of birch pollen: theoretical considerations and a feasibility study. Int. J. Biometeorol. 50, 392-402.

Sofiev, M., Belmonte, J., Gehrig, R., Izquierdo, R., Smith, M., Dahl, A., Siljamo, P., 2012. A review of production, release, distribution and health impact of allergenic pollen. In: Bergman, K.-C. (Ed.), Sofiev, M. Springer, Airborne pollen transport, pp. 127-159.

Sofiev, M., Berger, U., Prank, M., Vira, J., Arteta, J., Belmonte, J., Bergmann, K.-C., Chéroux, F., Elbern, H., Friese, E., et al., 2015. MACC regional multi-model ensemble simulations of birch pollen dispersion in Europe. Atmos. Chem. Phys. 15, 8115-8130.

Spieksma, F.T.M., Emberlin, J., Hjelmroos, M., Jäger, S., Leuschner, R.M., 1995. Atmospheric birch (Betula) pollen in Europe: trends and fluctuations in annual quantities and the starting date of the seasons. Grana 34, 51-57.

Stohl, A., 1996. Trajectory statistics - a new method to establish source-receptor relationships of air pollutants and its applications to the transport of particulate sulphate in Europe. Atmos. Environ. 30, 579-587.

Veriankaite, L., Siljamo, P., Sofiev, M., Sauliene, I., Kukkonen, J., 2010. Modelling analysis of source regions of long-range transported birch pollen that influences allergenic seasons in Lithuania. Aerobiologia 26, 47-62.

Viander, M., Koivikko, A., 1978. The seasonal symptoms of hyposensitized and untreated hay fever patients in relation to birch pollen counts: correlations with nasal sensitivity, prick tests and RAST. Clin. Allergy 8, 387-396. 